\title{
PULMONARY THROMBOEMBOLISM IN AIDS PATIENT WITH CHRONIC VENOUS INSUFFICIENCY, PULMONARY TUBERCULOSIS AND BREAST CANCER: A CASE REPORT AND PATHOPHYSIOLOGY REVIEW
}

Juan José CORTEZ-ESCALANTE(1), Cleudson CASTRO(1), Gustavo Adolfo Sierra ROMERO(1), Luiza MATOS(1) \& Muhammad Wasif SAIF(2)

\section{SUMMARY}

Recent literature reports thrombotic episodes occurring in patients with HIV infection associated with other abnormalities including neoplasms and infections predisposing to a hypercoagulable state. We report a 47-year-old woman who developed pulmonary thromboembolism in association with HIV infection, pulmonary tuberculosis and breast cancer. She was treated with rifampin, isoniazid, pyrazinamide; heparin, phenprocoumon, zidovudine, lamivudine and efavirenz. Acid fast bacilli were visualized in a sputum smear and three months after, Mycobacterium tuberculosis was isolated from lymph node biopsy during a episode of immune reconstitution. The isolated mycobacteria showed sensitivity to all first-line drugs. HIV infection, breast cancer and pulmonary tuberculosis have several mechanisms that induce hypercoagulable state and can lead to thromboembolic complications. Pulmonary thromboembolism in this patient was a diagnostic challenge because of all the other severe diseases that she experienced at the same time.

KEYWORDS: Thrombosis; Pulmonary thromboembolism; HIV infection; AIDS; Tuberculosis.

\section{INTRODUCTION}

The development of pulmonary thromboembolism (PTE) in patients with the human immunodeficiency virus (HIV) infection is uncommon $^{13}$. Various hematological abnormalities have been associated with HIV, including a hypercoagulable state predisposing to the thromboembolic complications. It becomes worse with cancer, opportunistic infections or autoimmune diseases and also with the use of a wide chemotherapy ${ }^{25}$. PTE is a common, serious and potentially fatal complication of the deep venous thrombosis (DVT). Both of them are distinct but related aspects of the same dynamic disease process known as venous thromboembolism (VTE). An estimated 201,000 new cases occur in the United States every year, being 107,000 with DVT (without PTE) and 94,000 with PTE (with or without DVT) ${ }^{30}$. In the same population, PTE is estimated to cause 50,000 deaths annually ${ }^{16}$. The most stressful situation is that the majority of deaths due to PTE occur in patients who are not treated because the lack of opportune diagnosis ${ }^{4}$. The frequency and magnitude of VTE in people living with HIV/AIDS changes according to the study method. The reported incidence has ranged from $0.25 \%$ to $0.96 \%$ in clinical studies, but up to $17 \%$ at necropsy ${ }^{3}$. The risk of DVT in people living with HIV/AIDS is approximately 10 times greater than in the general population ${ }^{24}$. In Brazil, researchers reported data based on necropsies, GOLIN et al. (2002), found 4.7\% prevalence of PTE in 16,466 necropsies during 24 years in a tertiary level hospital, and YOO et al. (2003) $10.6 \%$ in 4813 necropsies in a period of 20 years in a similar scenario ${ }^{12,36}$.

It is known the relationship among the hypercoagulable state and cancers. The most common tumor sites are colon, lung and prostate in men, and breast, lung and ovary in women ${ }^{18}$. In the breast cancer patient, the prevalence of DVT/PTE is 22 per $10,000^{19}$ and the incidence of VTE vary from as low as $0.1 \%$ in stage I disease in untreated patients to as high as $18 \%$ in stage III/IV disease in patients treated with chemotherapy and hormones ${ }^{22}$. AIDS-related malignancies such as Kaposi's sarcoma, non-Hodgkin's lymphoma, Hodgkin's lymphoma have been associated with DVT ${ }^{5,15}$. Frequency of VTE in patients with tuberculosis is variable. DVT is clinically obvious in $3.4 \%$ of the patients with pulmonary tuberculosis ${ }^{35}$. However, the real incidence may be closer to $10 \%$, because, ANDERSON et al. (1991), reported that one-third of all such cases are thought to be apparent ${ }^{1}$. ROBSON et al. (1996), found that $7.38 \%$ of their patients with pulmonary tuberculosis presented PTE $^{23}$. We report a patient with AIDS, pulmonary tuberculosis, breast cancer and chronic venous insufficiency at the University Hospital of the University of Brasilia.

\section{CASE REPORT}

A 47-year-old woman with past medical history of chronic venous

Research funded by CNPq.

(1) Núcleo de Medicina Tropical, Universidade de Brasília, Brasília, D.F. Caixa Postal 04517. Campus Universitário Darcy Ribeiro, Asa Norte, 70904-970 Brasília, DF, Brasil.

(2) Yale University School of Medicine. Section of Medical Oncology. 333 Cedar Street; FMP 116, New Haven, CT 06520, USA.

Correspondence to: Juan José Cortez-Escalante. Núcleo de Medicina Tropical, Universidade de Brasília, Caixa Postal 04517. Campus Universitário Darcy Ribeiro, Asa Norte, 70904-970 Brasília, DF, Brasil. Phone: +55 61 96562675; +55 61 2735008, Fax: 005561 2732811. E-mail: jcorteze@unb.br 
CORTEZ-ESCALANTE, J.J.; CASTRO, C.; ROMERO, G.A.S.; MATOS, L. \& SAIF, M.W. - Pulmonary thromboembolism in AIDS patient with chronic venous insufficiency, pulmonary tuberculosis and breast cancer: a case report and pathophysiology review. Rev. Inst. Med. trop. S. Paulo, 48(2):105-108, 2006.

insufficiency in the lower extremities for 18 years initially presented with weakness, fever, night sweats, and weight loss of $12 \mathrm{~kg}$ over six months. Review of systems included pain in the epigastrium, mild dyspnea on exertion, and productive cough at the last four weeks. Patient denied history of hormonal contraception use or hormone replacement therapy. Physical examination demonstrated pale mucosa, tachypnea (26 breaths/min), crackles on bilateral lungs auscultation, a hard, mobile nodule of $4 \mathrm{~cm}$ of diameter in the upper outer quadrant of the left breast without inflammatory signs. Scars of old ulcers were observed in both legs. Chest radiographies and computed tomography-CT (Fig. 1) showed interstitial infiltrates in the lower two-thirds of both lungs. A mammography and a breast biopsy showed two nodules, one of them compatible with malignancy. Histopathology of the cervix showed mild dysplasia and alterations compatible with human papillomavirus (HPV) infection. Initial laboratorial evaluation showed positive HIV serology, sputum positive for acid-fast bacillus, hemoglobin of $9.6 \mathrm{~g} / \mathrm{dL}$, leukocytes of 7,400 cells $/ \mu \mathrm{L}$, platelets of 204,000 cells $/ \mu \mathrm{L}$, aspartate aminotransferase (AST) of $97 \mathrm{UI} / \mathrm{L}$, alanine aminotransferase (ALT) of $64 \mathrm{UI} / \mathrm{L}$, lactate dehydrogenase $(\mathrm{LDH})$ of $508 \mathrm{UI} / \mathrm{L}$, alkaline phosphatase of $363 \mathrm{UI} / \mathrm{L}$ and total protein of $8.2 \mathrm{~g} / \mathrm{dL}$ (albumin of 3.2 $\mathrm{g} / \mathrm{dL}$ and globulin of $5 \mathrm{~g} / \mathrm{dL}$ ). The CD4+ T cell count was of 38 cell/ $\mu \mathrm{L}, \mathrm{CD} 8+$ of 188 cell $/ \mu \mathrm{L}(\mathrm{CD} 4 / \mathrm{CD} 8=0.20)$ and the viral load was of $340,007$ copies ( $\log 5.531)$. The tuberculin skin test (PPD) was negative. The repeat chest $\mathrm{X}$-ray continued showing the same patterns detected in the first radiography, one month before. During hospitalization antituberculosis therapy (ATT) was introduced with rifampin, isoniazid and pyrazinamide. Following ATT, on fifth day, she developed progressive dyspnea, tachypnea (34 breaths/min) and tachycardia (100 beats/min). On tenth day, she complained of acute chest pain in the right anterior hemithorax with irradiation to the back on the same side, which worsened during the inspiration. Differential diagnosis included a concomitant infection like Pneumocystis carinii pneumonia or PTE. Trimethoprim/sulfamethoxazole and heparin in prophylactic dose were initiated. The CT pulmonary angiography revealed PTE in both main pulmonary arteries, with extension to the lobar and segmental arteries of the right lower lobe and to the lobar arteries of the left lower lobe (Fig. 2). Therefore, anticoagulant therapy with heparin and oral phenprocoumon was administered. The levels of activated partial thromboplastin time (PPT) were between 1.12 to 1.54 times normal

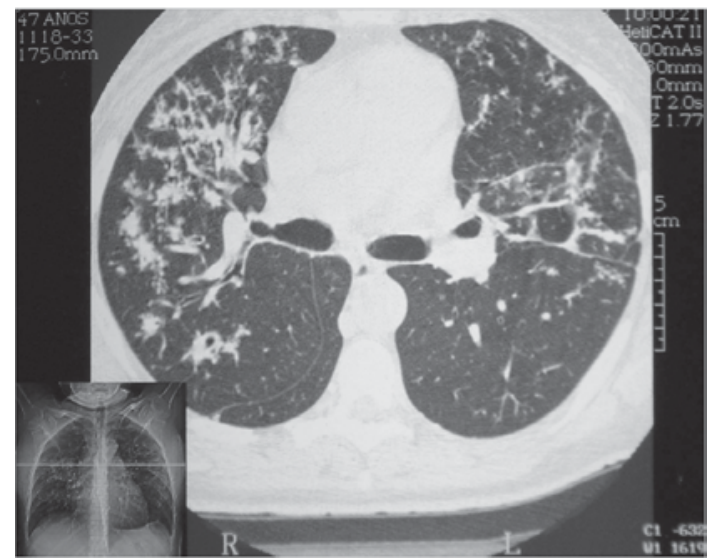

Fig. 1 - Chest CT: Infiltrative lesions in lungs and cavitary lesion in the upper segment of the lower left lobe, one month before hospitalization.
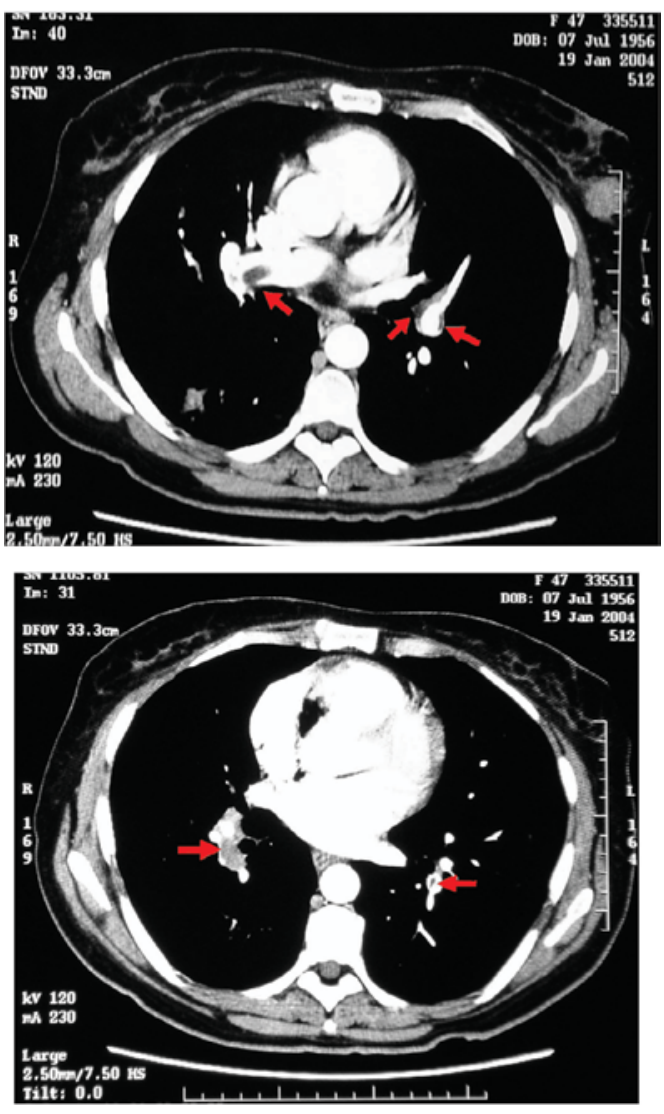

Fig. 2 - CT pulmonary angiography (a, b,): Thromboembolus (arrows) that obstruct the pulmonary arteries and their branches.

and the levels of prothrombin time (PT) were frequently with an international normalized ratio (INR) $<2$. Few days after beginning this therapy, the patient felt a significant improvement of the dyspnea. After three months of ATT and highly active antiretroviral therapy (HAART), she evolved with the immune reconstitution syndrome, with cervical lymph-nodes of approximately 3.5 to $5 \mathrm{~cm}$ of diameter with identification of the Mycobacterium tuberculosis in the acid-fast stain and in the culture of lymph-node biopsy. The isolated mycobacteria was sensitive to all ATT drugs, therefore, the medical indication was to continue without modifications of the established therapy. She had a mastectomy with axillary lymph-nodes removed. The diagnostic was invasive ductal carcinoma, with a size of $3 \times 2.7 \times 2.5 \mathrm{~cm}$, a surrounding border of cancer-free tissue, and the nearby lymph nodes. An Estrogen Receptor/Progesterone Receptor immunohistochemical investigation was negative. Nowadays, 23 months after the acute PTE episode, she stopped the anticoagulant therapy, continuing with low-dose aspirin and she remains cured of tuberculosis. Her therapeutic response to HAART was excellent maintaining undetectable levels of viral HIV load and CD4+ cell counts above 200/ $\mu \mathrm{L}$.

\section{REVIEW}

Many risk factors are involved in the development of PTE, these are the same for thrombus formation within the venous circulation, 
which can be grouped into three basic mechanisms as follows: venous stasis, injury to the vessel wall and hypercoagulability states, described by Virchow more than 100 years ago ${ }^{4}$. In patients with HIV infection several abnormalities were detected that predispose to the hypercoagulability state, including endothelial cell injury ${ }^{10}$, low-grade disseminated intravascular coagulopathy ${ }^{9}$, interference with the anticoagulation factors ${ }^{6,9,26,32}$ and the use of the drugs as protease inhibitors ${ }^{31}$. The abnormalities of anticoagulant factors are characterized by the presence of antiphospholipid antibodies (lupus anticoagulant, anticardiolipin, antiprothrombin and antibeta-2 glycoprotein I), deficiencies of the protein $\mathrm{C}^{9}$, protein $\mathrm{S}^{17}$, heparin cofactor $\mathrm{II}^{32}$ and antithrombin $\mathrm{III}^{26}$; as well as enhanced levels of von Willebrand factor and D-dimers 9 . This abnormalities are related to the severity of the underlying immunosuppression (Low CD4+ T cell count), opportunistic infections and malignancy induced by the HIV infection ${ }^{6}$. FEFFER et al. (1995), reported that HIV patients with CD4+ counts below 200 cell $/ \mu \mathrm{L}$ presented those alterations more frequently that those with CD4+ counts above 400 cell $/ \mu \mathrm{L}^{9}$. At least, some of those alterations could be present in our patient and contributed to the development of PTE. These abnormalities of anticoagulation factors could be reverted with the specific therapy of the opportunistic infections ${ }^{6}$ and antiretroviral therapy ${ }^{25}$. The association of cancer and thrombosis is well described and certain neoplasms, including breast cancer, are strongly associated with an increased frequency of thromboembolic events. In the primary breast cancer, the neoplastic cells produce an important quantity of tissue factor, the major extrinsic pathway procoagulant, independently of the clinical stage of the breast cancer ${ }^{29,34}$. In addition, the chemotherapeutic and hormonal agents used to treat breast cancer are associated with damage to vascular endothelium, lowered levels of endogenous anticoagulants (protein $\mathrm{C}$, protein $\mathrm{S}$ and antithrombin III) and an increased incidence of thrombosis, in both the adjuvant and metastatic setting ${ }^{21,27}$. Severe pulmonary tuberculosis is sometimes complicated by hypercoagulability states. These patients have lower levels of anticoagulation factors (protein $C$, protein $S$, antithrombin III), with elevation in plasma fibrinogen, factor VIII, fibrinolytic protein PAI-1 and D-dimers. All these alterations improve during the first 12 weeks of anti-tuberculosis therapy ${ }^{23,33}$. Anticardiolipin antibodies are found in these patients, although relationship was not demonstrated with the appearance of thromboembolic complications ${ }^{28}$. Some hypercoagulability abnormalities in tuberculosis patients can be explained. The Mycobacterium tuberculosis is able to activate macrophages directly and induces them to produce cytokines ${ }^{11}$. Some cytokines induce thrombosis, especially TNF-alpha, IL-1 and IL-6. TNF and IL-1 block the protein C anticoagulant pathway and can elicit tissue factor production on endothelium and monocytes. Thus, cytokines induce tissue factor formation intravascularly. This contrasts with the normal situation in which tissue factor is located exclusively in the extravascular space, largely on fibroblasts, where it is expressed constitutively ${ }^{7,8}$. The IL-6 can stimulate new platelets formation which have increased sensitivity to thrombin activation and increased procoagulant activity ${ }^{2}$. The presence of pulmonary tuberculosis with cavitation in HIV patients with CD4+ counts below 200 cells/ $\mu \mathrm{L}$ is an uncommon finding. Mycobacterium tuberculosis, in immunocompetent subjects, induces an early and late immune response that ultimately destroys most tubercle bacilli and usually prevents development of clinical disease. Early response is characterized by the presence of macrophages with other immune cells and the late response is dependent on the acquisition of CD4+ T cell-mediated immunity and characterized by granuloma formation ${ }^{14}$. In immunodeficient AIDS patients it does not happen, the immune response reacts poorly and form few cavitary lesions in the pulmonary parenchyma ${ }^{20}$.

Because of the multitude of associated medical conditions and pharmacological agents usually used to treat AIDS patients, anticoagulation should only be started after a definitive diagnosis has been made. Duplex ultrasound and venography remain the diagnostic studies of choice to identify those patients who need anticoagulant therapy and should be used aggressively in securing the diagnosis. Although the relationship between the degree of immunosuppression and incidence of thrombosis is not know but we found similar findings as earlier published in our retrospective study of 131 patients $^{26}$. Thromboembolism is particularly worrisome, and its sequelae can lead to sudden death (pulmonary embolus) in young patients. High degree of suspicion should be made in patients with HIV infection who present with signs and symptoms suggestive of VTE or PTE in spite of their younger age. Therefore, clinicians caring for these patients should be aware of the abnormalities which broaden the differential diagnosis of patients infected with HIV. Further studies aimed to elucidate the etiology of these proteins and related antibodies are needed.

Finally, the human immunodeficiency virus infection, breast cancer and pulmonary tuberculosis have several mechanisms that lead hypercoagulable state and can start venous thromboembolic complications like pulmonary thromboembolism. Pulmonary tuberculosis can disguise the apparition of PTE, as well as opportunistic infections in AIDS patients. Diagnostic and treatment of PTE in AIDS patients are similar with non-AIDS patients. HAART and antituberculosis therapy could revert the hematological abnormalities that activate venous thromboembolism. Clinicians should be aware of unprovoked thrombosis as a possible complication of AIDS and in the differential of other pathologies such as PTE may mimic opportunistic lung infections. In cases of unexplained thromboembolic events in young patients, HIV testing should be considered, at least in high risk groups.

\section{RESUMO}

\section{Tromboembolismo pulmonar em uma paciente com AIDS com insuficiência venosa profunda, tuberculose pulmonar e câncer de mama: relato de um caso e revisão da fisiopatologia}

Publicações recentes relatam episódios trombóticos em pacientes infectados pelo HIV associados a outras condições que incluem neoplasias e infecções que predispõem para um estado de hipercoagulabilidade. Relata-se o caso de uma paciente de 47 anos portadora do HIV que desenvolveu tromboembolismo pulmonar, tuberculose pulmonar e câncer de mama. Foi tratada com rifampicina, isoniazida, pirazinamida, heparina, femprocumona, zidovudina, lamivudina e efavirenz. Bacilos ácido-álcool-resistentes foram observados no exame de escarro e três meses depois foi isolado o Mycobacterium tuberculosis da biópsia de linfonodo durante um episódio de reconstituição imune. A micobactéria isolada demonstrou sensibilidade a todas as drogas anti-tuberculosas de primeira linha. A infecção pelo HIV, o câncer de mama e a tuberculose pulmonar possuem vários mecanismos que induzem um estado de hipercoagulabilidade $\mathrm{e}$ que podem produzir complicações tromboembólicas incluindo o TEP 
nos pacientes com AIDS. O TEP nesta paciente foi um desafio diagnóstico, considerando todas as outras doenças graves que apresentou simultaneamente.

\section{REFERENCES}

1. ANDERSON Jr., F.A.; WHEELER, H.B.; GOLDBERG, R.J. et al. - Physician practices in the prevention of venous thromboembolism. Ann. intern. Med., 115: 591-595, 1991.

2. BURSTEIN, S.A.; PENG, J.; FRIESE, P. et al. - Cytokine-induced alteration of platelet and hemostatic function. Stem Cells, 14 (suppl. 1): 154-162, 1996.

3. COPUR, A.S.; SMITH, P.R.; GOMEZ, V.; BERGMAN, M. \& HOMEL, P. - HIV infection is a risk factor for venous thromboembolism. AIDS Patient Care STDS, 16: 205 209, 2002 .

4. DALEN, J.E. - Pulmonary embolism: what have we learned since Virchow? Natural history, pathophysiology, and diagnosis. Chest, 122: 1440-1456, 2002.

5. DOBERSON, M.J. \& KLEINSCHMIDT-DeMASTERS, B.K. - Superior sagittal sinus thrombosis in a patient with acquired immunodeficiency syndrome. Arch. Path. Lab. Med., 118: 844-846, 1994.

6. ERBE, M.; RICKERTS, V.; BAUERSACHS, R.M. \& LINDHOFF-LAST, E. - Acquired protein $\mathrm{C}$ and protein $\mathrm{S}$ deficiency in HIV-infected patients. Clin. appl. Thromb. Hemost., 9: 325-331, 2003.

7. ESMON, C.T. - Possible involvement of cytokines in diffuse intravascular coagulation and thrombosis. Baillieres Best Pract. Res. clin. Haemat., 12: 343-359, 1999.

8. ESMON, C.T. - Crosstalk between inflammation and thrombosis. Maturitas, 47: 305 314,2004

9. FEFFER, S.E.; FOX, R.L.; ORSEN, M.M.; HARJAI, K.J. \& GLATT, A.E. - Thrombotic tendencies and correlation with clinical status in patients infected with HIV. Sth med. J. (Bgham, Ala.), 88: 1126-1130, 1995.

10. FRIEDMAN, S.M. \& MARGO, C.E. - Bilateral central retinal vein occlusions in a patient with acquired immunodeficiency syndrome. Clinicopathologic correlation. Arch. Ophthal., 113: 1184-1188, 1995.

11. GIACOMINI, E.; IONA, E.; FERRONI, L. et al. - Infection of human macrophages and dendritic cells with Mycobacterium tuberculosis induces a differential cytokine gene expression that modulates T cell response. J. Immunol., 166: 7033-7041, 2001.

12. GOLIN, V.; SPROVIERI, S.R.; BEDRIKOW, R. \& SALLES, M.J. - Pulmonary thromboembolism: retrospective study of necropsies performed over 24 years in a university hospital in Brazil. S. Paulo med. J., 120: 105-108, 2002.

13. HOWLING, S.J.; SHAW, P.J. \& MILLER, R.F. - Acute pulmonary embolism in patient with HIV disease. Sex. transm. infect., 75: 25-29, 1999.

14. KAUFMANN, S.H. - Immunity to intracellular bacteria. Ann. Rev. Immunol., 11: 129 $163,1993$.

15. KAUFMANN, T.; NISCE, L.Z. \& METROKA, C. - Thromboembolism in AIDS-related Kaposi's sarcoma. J. Amer. med. Ass., 266: 2834, 1991.

16. KROEGEL, C. \& REISSIG, A. - Principle mechanisms underlying venous thromboembolism: epidemiology, risk factors, pathophysiology and pathogenesis. Respiration, 70: 7-30, 2003

17. LAFEUILLADE, A.; SORICE, M.; GRIGGI, T. et al. - Role of autoimmunity in protein S deficiency during HIV-1 infection. Infection, 22: 201-203, 1994.

18. LEE, A.Y. - Epidemiology and management of venous thromboembolism in patient with cancer. Thromb. Res., 110: 167-172, 2003.
19. LEVITAN, N.; DOWLATI, A.; REMICK, S.C. et al. - Rates of initial and recurrent thromboembolic disease among patients with malignancy versus those without malignancy. Risk analysis using Medicare claims data. Medicine (Baltimore), 78: 285-291, 1999.

20. PERLMAN, D.C.; EL-SADR, W.M.; NELSON, E.T. et al. - Variation of chest radiographic patterns in pulmonary tuberculosis by degree of human immunodeficiency virusrelated immunosuppression. The Terry Beirn Community Programs for Clinical Research on AIDS (CPCRA). The AIDS Clinical Trials Group (ACTG). Clin. infect. Dis., 25: 242-246, 1997

21. RICKLES, F.R. \& FALANGA, A. - Molecular basis for the relationship between thrombosis and cancer. Thromb. Res., 102: V215-224, 2001.

22. RICKLES, F.R.; PATIERNO, S. \& FERNANDEZ, P.M. - Tissue factor, thrombin, and cancer. Chest, 124 (suppl. 3): 58S-68S, 2003.

23. ROBSON, S.C.; WHITE, N.W.; ARONSON, I. et al. - Acute-phase response and the hypercoagulable state in pulmonary tuberculosis. Brit. J. Haemat., 93: 943-949, 1996.

24. SABER, A.A.; ABOOLIAN, A.; LARAJA, R.D.; BARON, H. \& HANNA, K. - HIV/ AIDS and the risk of deep vein thrombosis: a study of 45 patients with lower extremity involvement. Amer. Surg., 67: 645-647, 2001.

25. SAIF, M.W. \& GREENBERG, B. - HIV and thrombosis: a review. AIDS Patient Care STDS, 15: 15-24, 2001

26. SAIF, M.W.; BONA, R. \& GREENBERG, B. - AIDS and thrombosis: retrospective study of 131 HIV-infected patients. AIDS Patient Care STDS, 15: 311-320, 2001.

27. SAIF, M.W.; LEITMAN, S.F.; CUSACK, G. et al. - Thromboembolism following removal of femoral venous apheresis catheters in patients with breast cancer. Ann. Oncol., 15: $1366-1372,2004$

28. SANTIAGO, M.B.; COSSERMELLI, W.; TUMA, M.F.; PINTO, M.N. \& OLIVEIRA, R.M. - Anticardiolipin antibodies in patients with infectious diseases. Clin. Rheumat., 8: $23-28,1989$.

29. SHOJI, M.; HANCOCK, W.W.; ABE, K. et al. - Activation of coagulation and angiogenesis in cancer: immunohistochemical localization in situ of clotting proteins and vascular endothelial growth factor in human cancer. Amer. J. Path., 152: 399-411, 1998.

30. SILVERSTEIN, M.D.; HEIT, J.A.; MOHR, D.N. et al. - Trends in the incidence of deep vein thrombosis and pulmonary embolism: a 25 -year population-based study. Arch. intern. Med., 158: 585-593, 1998.

31. SULLIVAN, P.S.; DWORKIN, M.S.; JONES, J.L. \& HOOPER, W.C. - Epidemiology of thrombosis in HIV-infected individuals. The Adult/Adolescent Spectrum of HIV Disease Project. Aids, 14: 321-324, 2000.

32. TOULON, P.; LAMINE, M.; LEDJEV, I. et al. - Heparin cofactor II deficiency in patients infected with the human immunodeficiency virus. Thromb. Haemost., 70: 730735, 1993.

33. TURKEN, O.; KUNTER, E.; SEZER, M. et al. - Hemostatic changes in active pulmonary tuberculosis. Int. J. Tuberc. Lung Dis., 6: 927-932, 2002.

34. UENO, T.; TOI, M.; KOIKE, M.; NAKAMURA, S. \& TOMINAGA, T. - Tissue factor expression in breast cancer tissues: its correlation with prognosis and plasma concentration. Brit. J. Cancer, 83: 164-170, 2000.

35. WHITE, N.W. - Venous thrombosis and rifampicin. Lancet, 2: 434-435, 1989.

36. YOO, H.H.; DE PAIVA, S.A.; SILVEIRA, L.V. \& QUELUZ, T.T. - Logistic regression analysis of potential prognostic factors for pulmonary thromboembolism. Chest, 123: 813-821, 2003.

Received: 27 June 2005

Accepted: 5 December 2005 